\title{
PENGARUH PERENCANAAN PAJAK, BEBAN PAJAK TANGGUHAN, DAN \\ PROFITABILITAS TERHADAP MANEJEMEN LABA PADA PERUSAHAAN SEKTOR UTAMA YANG TERDAFTAR DI BURSA EFEK INDONESIA PERIODE 2010-2018
}

\author{
Yukha Kamila \\ Universitas Muhammadiyah Prof. Dr. HAMKA \\ yukhakha@gmail.com
}

\begin{abstract}
Abstrak: Manajemen laba adalah suatu kondisi dimana manajemen melakukan intervensi dalam proses penyusunan laporan keuangan bagi pihak eksternal sehingga dapat meratakan, menaikkan, dan menurunkan laba. Penelitian ini bertujuan untuk menganalisa pengaruh perencanaan pajak, beban pajak tangguhan dan profitabilitas terhadap manajemen laba pada perusahaan sektor utama yang terdapat di bursa efek Indonesia (BEI) periode 2010-2018. Penelitian ini merupakan penelitian kuantitatif. Pemilihan sampel dilakukan dengan metode purposive sampling. Data yang digunakan adalah data sekunder. Metode analisis data menggunakan analisis regresi berganda. Populasi data dalam penelitian ini adalah semua perusahaan sektor utama yang terdaftar dalam Bursa Efek Indonesia (BEI) periode tahun 2010-2018. Sampel sejumlah 5 perusahaan.Hasil penelitian menunjukan bahwa secara parsial perencanaan pajak, beban pajak tangguhan, dan profitabilitas tidak memiliki pengaruh yang signifikan terhadap manajemen laba. Secara simultan perencanaan pajak, beban pajak tangguhan, dan profitabilitas tidak memiliki pengaruh yang signifikan terhadap manajemen laba.
\end{abstract}

Kata Kunci : Pajak, profitabilitas, perencanaan, laba

Abstract : Earnings management is a condition in which management intervenes in the process of preparing financial reports for external parties so that it can even, increase and decrease profits. This study aims to analyze the effect of tax planning, deferred tax burden and profitability on earnings management in the main sector companies listed on the Indonesian Stock Exchange (BEI) 2010-2018. This research is a quantitative research. The sample selection was done by using purposive sampling method. The data used are secondary data. Methods of data analysis using multiple regression analysis. The data population in this study were all major sector companies listed on the Indonesia Stock Exchange (BEI) for the period 2010-2018. The sample is 5 companies.The results showed that partially tax planning, deferred tax expense, and profitability did not have a significant effect on earnings management. Simultaneously, tax planning, deferred tax expense, and profitability do not have a significant effect on earnings management.

Keywords: Tax, Profitability, Planning, Profit

\section{PENDAHULUAN}

Semakin tingginya persaingan dalam dunia usaha dan semakin majunya perkembangan zaman kinerja atau performa yang baik sangat dibutuhkan dalam menghadapi persaingan usaha. Persaingan usaha saat ini terasa semakin kompetitif sehngga menyebabkan adanya tuntutan bagi perusahaan agar membuat manajemen semakin efisien dan kreatif dalam segala ativitas, sehingga optimalisasi sumber daya manusia sangat diperlukan agar perusahaan bisa mendapatkan laba yang semakin banyak. 
Salah satu strategi dalam menjalan kan usaha adalah dengan terus menarik investor untuk melakukan kerja sama dan menanamkan modalnya didalam usaha kita. Cara untuk menapatkan investor dan calon investor adalah menunjukkan laba perusahaan yang diperoleh, karena laba merupakan salah satu indikator yang paling sederhana untuk melihat baik / tidaknya perusahaan kita. Sebuah perusahaan mempunyai daya tarik tersendiri yang digunakan sebagai pertimbangan, dan informasi tentang laba (earnings) yang menjadi daya tarik utamanya.

Suatu kewajiban bagi beberapa pihak yang berkepentingan yang digunakan sebagai pertimbangan dalam mengambil sebuah keputusan penting seperti pemberian kompensasi, dan pembagian bonus kepada manejer, dan dasar penentuan besarnya pengenaan pajak yaitu menganalisa laporan keuangan. Sebab itu, kualitas laba yag baik menjadi pusat perhatian bagi investor, kreditor, pembuatan kebijakan akuntansi, dan pemerintah dalam hal ini adalah Direktorat Jenderal Pajak. Perhatian investor yang sering terpusat pada informasi labalah tanpa melihat prosedur yang digunakan untuk menghasilkan informasi laba tersebut memotivasi manajer untuk terus menaikan laba perusahaannya, dan terus mempercantik laporan keuangan perusahaan.

Dan pihak manajemen akan mendapatkan bonus yang tinggi juga karena semakin tinggi dia memperoleh laba, semakin tinggi juga dia mendapatkan bonus. Di lain pihak, informasi laba dapat membantu pemilik (stakeholders) dalam mengestimasi kekuatan laba (earning power) untuk menaksir resiko dalam investasi dan kredit. Pentingnya informasi laba tersebut merupakan tanggung jawab dari pihak manajemen yang diukur kinerjanya dari pencapaian laba yang diperoleh. Situasi ini memungkinkan manajer untuk melakukan perilaku menyimpang dalam menyajikan dan melaporkan informasi laba tersebut yang dikenal dengan praktik manajemen laba (earnings management).

Manajemen laba (earning management) adalah kegiatan mempercantik laporan keuangan tentang laba sesuai dengan keinginan pihak tertentu khususnya manajemen perusahaan. Tindakan earnings management sebenarnya didasarkan oleh berbagai tujuan dan maksud-maksud yang terkandung didalamnya, Irham Fahmi (2013:279). Sedangkan menurut Sastradipaja (2013:25) peningkatan laba menggambarkan peningkatan nilai perusahaan secara keseluruhan dan sebaliknya, Terutama untuk menyembunyikan kerugian-kerugian perusahaan, laba diatur untuk menunjukkan situasi yang menguntungkan perusahaan. Siasat perusahaan untuk merubah informasi tentang laba yang diperolehnya tidaklah lagi mencerminkan informasi tentang laba yang sesungguhnya.

Sebab itu, praktik merekayasa laporan keuangan bukanlah sesuatu hal yang baru dan dianggap lurah oleh sebagian orang, 
dampaknya dari perekayasaan laporan keuangan dapat merugikan sebagian pihak karena mengubah fakta yang sebenernya telah terjadi didalam perusahaan itu. Karena bagi manajer perusahaan jika laporan perusahaan dia baik maka perusahaan akan mendapatkan lebih banyak investor lagi.

Manajemen laba (earning management) merupakan suatu tindakan yang mengatur laba sesuai dengan yang dikehendaki oleh pihak tertentu atau terutama oleh manajemen perusahaan (company management). Tindakan earnings management sebenarnya didasarkan oleh berbagai tujuan dan maksudmaksud yang terkandung didalamnya, Irham Fahmi (2013:279). Sedangkan menurut Sastradipaja (2013:25) peningkatan laba menggambarkan peningkatan nilai perusahaan secara keseluruhan dan sebaliknya, Terutama untuk menyembunyikan kerugian-kerugian perusahaan, laba diatur untuk menunjukkan situasi yang menguntungkan perusahaan. Upaya perusahaan untuk merekayasa informasi melalui praktik manajemen laba telah menjadi faktor utama yang menyebabkan laporan keuangan tidak lagi mencerminkan nilai fundamental suatu perusahaan. Oleh karena itu, perekayasaan laporan keuangan telah menjadi isu sentral sebagai sumber penyalahgunaan informasi yang dapat merugikan pihak-pihak berkepentingan itulah sebabnya informasi yang disampaikan terkadang diterima tidak sesuai dengan kondisi perusahaan yang sebenarnya. Karena bagi manajer perusahaan jika laporan perusahaan dia baik maka perusahaan akan mendapatkan lebih banyak investor lagi.

Perencanaan pajak adalah langkah awal dalam melakukan manajemen pajak. Pada tahap ini dilakukan pengumpulan dan penelitian terhadap peraturan perpajakan agar dapat diseleksi jenis tindakan penghematan pajak yang akan dilakukan. Pada umumnya penekanan perencanaan pajak (tax planning) adalah untuk meminimumkan kewajiban pajak Erly Suandy (2011:6). Hal tersebut sesuai dengan penelitian oleh Husnul Khotimah (2014) menunjukkan bahwa perencanaan pajak berpengaruh positif terhadap laba bersih. Beban pajak tangguhan adalah beban yang timbul akibat perbedaan temporer antara laba akuntansi (laba dalam laporan keuangan untuk pihak eksternal) dengan laba fiskal (laba yang digunakan sebagai dasar perhitungan pajak), Harmanto (2011:115). Hal tersebut sesuai dengan penelitian oleh Ghafara Mawaridi Mazini Tundjung (2015) beban pajak tangguhan berpengaruh positif signifikan terhadap manajemen laba. Sementara menurut Hadi Kusuma Ningrat (2014) hasil penelitian bahwa beban pajak tangguhan tidak berpengaruh signifikan terhadap probabilitas perusahaan dalam melakukan manajemen laba.

Profitabilitas sebagai salah satu rasio keuangan merupakan rasio yang digunakan untuk mengukur efisiensi perusahaan dalam 
menghasilkan laba dari penjualan maupunn pendapatan investasi selama periode tertentu, Irham Fahmi (2013:135). Profitabilitas ini lebih diitekankan karena untuk dapat melangsungkan hidupnya suatu perusahaan haruslah berada dalam keadaan yang menguntungkan baik secara jangka pendek maupun secara jangka panjang. Perusahaan yang memiliki profitabilitas yang tinggi maka laba yang dihasilkan juga akan samakin tinggi, hal ini akan berhubungan dengan jumlah kompensasi atau bonus yang akan diterima manajemen. Hal tersebut sesuai dengan penelitian oleh Najmi Yatulhusna (2015) mengemukakan bahwa profitabilitas berpengaruh signifikan terhadap manajemen laba. Sementara menurut Pipit Widhi Astuti (2017) hasil penelitian ini menunjukkan bahwa profitabilitas tidak berpengaruh terhadap manajemen laba.

\section{METODE PENELITIAN}

Pengambilan sampel dalam penelitian ini menggunakan purposive sampling, yaitu teknik penentuan sampel berdasarkan pertimbangan tertentu. Pertimbangan tersebut antara lain :

1. Terdaftar sebelum 1 Januari 2010

2. Perusahaan yang tidak berpindah sektor.

3. Perusahaan yang tidak mengalami delisting

4. Harus terdapat informasi keuangan yang diperlukan terkait dengan variable penelitian

5. Perusahaan yang memperoleh kerugian laba maksimal 5 periode / sampel..

\section{Analisis Akuntansi}

Analisis akuntansi dilakukan untuk melihat hubungan antar variabel independent dengan variabel dependent dengan melihat hasil perhitungan yang telah diolah. Analisis akuntansi yang dilakukan adalah sebagai berikut :

1. Menghitung besarnya nilai perencanaan pajak dengan menggunakan tax ratentation rate.

2. Menghitung besarnya nilai beban pajak tangguhan dengan menggunakan deferred tax expense.

3. Menghitung besarnya nilai profitabilitas dengan menggunakan rasio yaitu return on asset.

4. Menjelaskan perusahaan yang melakukan manajemen laba dan yang tidak melakukan manajemen laba.

\section{Analisis Statistik Deskriptif}

Analisis statistik deskriptif merupakan teknik deskriptif yang memberikan informasi mengenai data yang dimiliki dan tidak bermaksud menguji hipotesis. Analisis ini hanya digunakan untuk menyajikan dan menganalisis data disertai dengan perhitungan agar dapat memperjelas keadaan atau karakteristik data yang bersangkutan. Pengukuran yang digunakan dalam statistik despkriptif ini meliputi nilai rata-rata (mean), standar deviasi, varian, maksimum, minimun, sum, range,kurtosis dan skewness (kemencengan distribusi); (Ghozali, 2016). 
Analisis Regresi Logistik

\section{Model Regresi Logistik}

Menurut Imam Ghozali (2016:335) regresi positif yang variabel bebasnya merupakan kombinasi variabel kontinyu (metrik) dan kategorial (non- metrik) sedangkan variabel terikatnya bersifat katerogial (non-metrik).

\section{Menilai Model Fit (Uji Simultan)}

Selanjutnya, berdasarkan hasil output SPSS yang diperoleh akan dilakukan analisis pengujian model regresi logistik melalui beberapa tahapan, antara lain :

\section{Menilai Likelihood (Block Number)}

Untuk menilai overhall model fit dapat dilakukan dengan membandingkan dengan nilai Log Likelihood Value (-2LL) awal atau Block Number $=0$ (nol) dengan nilai Log Likelihood Value (-2LL) akhir atau Block Number $=1$ (satu). Jika terjadi penurunan nilai Log Likelihood (-2LL) dari Block Number $=0$ (nol) terhadap Block Number $=1$ (satu), maka menunjukkan model regresi yang lebih baik atau dengan kata lain model yang dihipotesiskan fit dengan data. Untuk melihat kemampuan variabel independent dalam menjelaskan variable dependent dapat dilihat melalui nilai Nagelkerke $R$ Square, nilai tersebut dapat diinterpestasikan seperti $\mathrm{R} 2$ pada regresi berganda biasa.

2. Koefisien Determinasi (Cox and Snell's $R$ Square)

Cox and Snell's $R$ Square merupakan ukuran yang mencoba miniru ukuran R2 pada multiple regression yang didasarkan pada teknik estimasi Likelihood dengan nilai maksimum kurang dari 1 (satu) sehingga sulit diinterprestasikan. Nagelkerke's $R$ Square merupakan modifikasi dari koefisien Cox and Snell $R$ Square untuk memastikan bahwa nilainya bervariasi dari 0 (nol) sampai 1 (satu). Hal ini dilakukan dengan cara membagi nilai Cox and Snell $R$ Square dengan nilai maksimumnya. Nilai Nagelkerke's $R \quad$ Square dapat diinterprestasikan seperti nilai R2 pada multiple regression.

3. Hosmer and Lemeshow's Goodness of Fit Test

Dalam regresi logistik untuk menilai kelayakan model dapat menggunakan Hosmer and Lemeshow's Goodness of Fit Test. Menurut Imam Ghozali (2016:340) cara ini digunakan untuk menguji bahwa data empiris cocok atau sesuai dengan model, artinya tidak ada perbedaan data sehingga model dapat dikatakan fit. Jika nilai Hosmer and Lameshow's Goodness of Fit Test sama dengan atau kurang dari 0,05 maka hipotesis 0 (nol) ditolak yang bearti ada perbedaan signifikan antara model dengan nilai observasinya sehingga Goodness Fit Model tidak baik karena model tidak dapat memprediksi nilai observasinya atau jika Hosmer and Lameshow's Goodness Of Fit Test lebih besar dari 0,05 dapat dikatakan model dapat diterima karena cocok dengan data observasinya.

\section{Uji Hipotesis Secara Parsial}

Dalam penelitian ini hipotesis kedua $\mathrm{X}_{1}$ (Perencanaan Pajak) secara parsial 
berpengaruh terhadap variabel terikat. Model ketiga digunakan untuk menguji hipotesis ketiga $\mathrm{X}_{2}$ (Beban Pajak Tangguhan) secara parsial berpengaruh terhadap variabel terikat. Model keempat digunakan untuk menguji hipotesis keempat $\mathrm{X}_{3}$ (Profitabilitas) secara parsial berpengaruh terhadap variabel terikat.

\section{HASIL PENELITIAN DAN PEMBAHASAN}

\section{Pengujuan Hipotesis dan Pembahasannya}

1. Pengaruh Perencanaan Pajak, Beban Pajak

Tangguhan, dan Profitabilitas terhadap

Manajemen Laba

Berdasarkan tabel Omnimbus Tests of Model Coefficients, dapat dinyatakan bahwa variabel perencanaan pajak, beban pajak tangguhan, dan profitabilitas secara bersamasama berpengaruh terhadap manajemen laba. Hal ini terlihat dari tabel 22 dimana nilai Chisquare 22,044 dengan tingkat signifikan sebesar $0,000<0,05$. Selain itu berdasarkan Nagelkerke $R$ Square pada tabel 20 menunjukkan nilai sebesar $100 \%$ variabel bebas dalam penelitian ini mampu menjelaskan variabel terikat.

2. Pengaruh Perencanaan Pajak terhadap Manajemen Laba

Hasil pengujian terhadap variabel perencanaan pajak memiliki tingkat signifikan sebesar 0,998 >0,05. Hal tersebut dapat diartikan bahwa variabel perencanaan pajak tidak berpengaruh secara signifikan terhadap manajemen laba atau dengan kata lain, $\mathrm{H}_{1}$ ditolak.
3. Pengaruh Beban Pajak Tangguhan terhadap Manajemen Laba

Hasil pengujian terhadap variabel beban pajak tangguhan memiliki tingkat signifikan sebesar $0,989>0,05$. Hal tersebut dapat diartikan bahwa variabel beban pajak tangguhan tidak berpengaruh secara signifikan terhadap manajemen laba atau dengan kata lain, $\mathrm{H}_{2}$ ditolak.

4. Pengaruh Profitabilitas terhadap Manajemen Laba

Hasil pengujian terhadap variabel profitabilitas memiliki tingkat signifikansi sebesar $0,972>0,05$. Hal tersebut dapat diartikan bahwa variabel profitabilitas tidak berpengaruh secara signifikan terhadap manajemen laba atau dengan kata lain, $\mathrm{H}_{3}$ ditolak.

Ketika laba yang dihasilkan perusahaan pada satu periode sangat tinggi, maka akan terdapat kemungkinan terjadi penurunan laba pada periode berikutnya. Hasil penelitian ini sesuai dengan bonus plan hypothesis yang dipaparkan dalam teori akuntansi positif dimana ketika perusahaan memperoleh laba yang semakin tinggi jauh diatas jumlah yang disyaratkan untuk memperoleh bonus, manajer akan megatur laba agar laba yang dilaporkan tidak terlalu besar sehingga kelebihan laba yang tidak dilaporkan dapat disajikan untuk laporan laba periode berikutnya. 


\section{PENUTUP}

\section{Kesimpulan}

Berdasarkan analisis data dan pembahasan yang dilakukan, dapat diambil kesimulan sebagai berikut :

1. Penelitian ini menggunakan teknik analisis regresi logistik. Berdasarkan pengujian regresi logistik, maka dapat dituliskan persamaan model regresi sebagai berikut :

$$
\begin{aligned}
\operatorname{Ln}=\frac{\mathrm{EM}}{1-\mathrm{EM}}=17,197+3,082 \mathrm{X} 1+4766,132 \mathrm{X} 2 \\
+3920,551 \times 3+e
\end{aligned}
$$

Hasil ini menunjukkan bahwa variabel perencanaan pajak $\left(\mathrm{X}_{1}\right)$, beban pajak tangguhan $\left(\mathrm{X}_{2}\right)$, dan profitabilitas $\left(\mathrm{X}_{3}\right)$ mempengaruhi manajemen laba $(\mathrm{Y})$. Tanda koefisien regresi positif untuk variabel perencanaan pajak $\left(\mathrm{X}_{1}\right)$ menunjukkan bahwa semakin tinggi perencanaan pajak $\left(\mathrm{X}_{1}\right)$ dengan asumsi beban pajak tangguhan $\left(\mathrm{X}_{2}\right)$, dan profitabiliitas $\left(\mathrm{X}_{3}\right)$ tetap, maka probabilitas perusahaan melakukan manajemen laba (Y) semakin tinggi dan sebaliknya. Tanda koefisien regresi positif untuk variabel beban pajak tangguhan $\left(\mathrm{X}_{2}\right)$ menunjukkan bahwa semakin tinggi beban pajak tangguhan $\left(\mathrm{X}_{2}\right)$ dengan asumsi perencanaan pajak $\left(\mathrm{X}_{1}\right)$, dan profitabilitas $\left(\mathrm{X}_{3}\right)$ tetap, maka probabilitas perusahaan melakukan manajemen laba (Y) semakin tinggi dan sebaliknya.

Sedangkan tanda koefisien regresi positif untuk variabel profitabilitas menunjukkan bahwa semakin tinggi nilai profitabilitas (X3) dengan asumsi perencanaan pajak (X1), dan beban pajak tangguhan (X2) tetap, maka probabilitas perusahaan melakukan manajemen laba (Y) semakin tinggi dan sebaliknya.

2. Hasil dari pengujian model fit, menunjukkan nilai -2LL awal sebesar 22,044 sedangkan nilai -2LL akhir sebesar 0,000. Setelah dimasukkan kedua variabel independen, maka nilai -22LL mengalami penurunan sebesar 22,044. Hal ini menunjukkan model regresi dikatakan layak atau dengan kata lain model yang dihipotesiskan fit dengan data.

3. Sedangkan kemampuan variabel bebas dalam menjelaskan variabel terikat dalam penelitian ini dapat dilihat dari nilai Nagelkerke $R$ Square yang dihasilkan yaitu sebesar 1,000 yang berarti variabilitas variabel dependen yang dapat dijelaskan oleh variabel independen adalah sebesar 100\% .Jika dijelaskan oleh Cox and Snell R Square dapat dijelaskan bahwa variabel independen dapat menjelaskan variabel dependen sebesar $38,7 \%$, sementara sisanya $61,3 \%$ dijelaskan oleh variabel lain yang tidak dimasukkan dalam penelitian ini, seperti aktiva pajak tangguhan, pajak kini, dan ukuran perusahaan. Berdasarkan uji Hosmer and Lemeshow Goodness of Fit Test menunjukan angka $0,999>0,05$ atau yang berarti model regresi layak untuk digunakan dalam analisis selanjutnya.

4. Hasil uji variabel independen dalam penelitian (perencanaan pajak, beban pajak tangguhan, dan profitabilitas) berdasarkan 
omnimbus test of model coefficient secara bersama-sama berpengaruh signifikan terhadap manajemen laba karena memiliki nilai $0,000<0,05$ atau dengan kata lain $\mathrm{H} 4$ diterima.

5. Berikut adalah hasil pengujian masing-masing variabel :

1) Hasil pengujian menunjukkan variabel pajak $\left(X_{1}\right)$ memiliki nilai signifikansi $0,998>0,05$. Hal tersebut dapat diartikan bahwa variabel perencanaan pajak tidak berpengaruh secara signifikan terhadap manajemen laba atau dengan kata lain $\mathrm{H} 1$ ditolak.

2) Hasil pengujian menunjukkan variabel beban pajak tangguhan $\left(\mathrm{X}_{2}\right)$ memiliki nilai signifikansi $0,989>0,05$. Hal tersebut dapat diartikan bahwa variabel beban pajak tangguhan tidak berpengaruh secara signifikan terhadap manajemen laba atau dengan kata lain $\mathrm{H} 2$ ditolak.

3) Hasil pengujian menunjukkan variabel profitabilitas $\left(\mathrm{X}_{3}\right)$ memiliki nilai signifikansi $0,972>0,05$. Hal tersebut dapat diartikan bahwa variabel profitabiltas tidak berpengaruh secara signifikan terhadap manajemen laba atau dengan kata lain $\mathrm{H} 3$ ditolak.

\section{Saran}

Berdasarkan kesimpulan di atas, penulis memberikan saran-saran sebagai berikut :

1. Variabel yang digunakan dalam penelitian ini ada 3 (tiga) yaitu perencanaan pajak, beban pajak tangguhan, dan profitabilitas, maka pada penelitian selanjutnya diharapkan dapat menambahkan variabel independen seperti aktiva pajak tangguhan, pajak kini, dan ukuran perusahaan.

2. Periode yang digunakan dalam penelitian ini selama 9 (sembilan) tahun, maka pada penelitian selanjutnya diharapkan dapat menambah lamanya periode penelitian dan penelitian selanjutnya diharapkan dapat mengembangkan penelitian ini dengan membandingkan antar sektor utama agar mendapatkan hasil penelitian yang lebih baik dan menarik.

3. Melaksanakan perencanaan pajak secara lebih baik lagi melalui penganalisaan informasi yang ada secara teliti, seperti mengikuti dan mengetahui perkembangan peraturan perpajakan terbaru.

4. Terkait dengan tidak signifikannya pengaruh beban pajak tangguhan terhadap manajemen laba, penelitian yang akan datang dapat melibatkan penggunaan komponen-komponen pembentuk pajak tangguhan seperti mengklasifikasikan kembali kewajiban dan aktiva pajak tangguhan perusahaan.

5. Penggunaan variabel profitabilitas dalam penelitian ini menggunakan proksi rasio profitabilitas yaitu return on assets, maka pada penelitian selanjutnya diharapkan dapat menggunakan proksi rasio profitabilitas lainnya seperti return on equity. 


\section{DAFTAR PUSTAKA}

Aditama, F. and Purwaningsih, A., 2016. Pengaruh perencanaan pajak terhadap manajemen laba pada perusahaan nonmanufaktur yang terdaftar di Bursa Efek Indonesia.

Amertha, I.S.P., 2013. Pengaruh Return on Asset pada Praktik Manajemen Laba dengan Moderasi Corporate Governance. E-Jurnal Akuntansi, 4(2), pp.373-387.

Andrea Y.G. and Halim, A., 2014. Perbandingan Kemampuan Beban Pajak Tangguhan dan Penyisihan Aktiva Pajak Tangguhan Entitas dalam Mendeteksi Manajemen Laba (Doctoral dissertation, [Yogyakarta]: Universitas Gadjah Mada).

Astuti, P.W., 2017. Pengaruh Profitabilitas, Ukuran Perusahaan, Leverage, Dan Kualitas Audit Terhadap Manajemen Laba. Universitas Muhammadiyah Surakarta.

Astutik, R.E.P. and Mildawati, T., 2016. Pengaruh perencanaan pajak dan beban pajak tangguhan terhadap manajemen laba. Jurnal Ilmu Dan Riset Akuntansi (JIRA), 5(3).

Azlina, N., 2010. Analisis Faktor Yang Mempengaruhi Manajamen Laba (Studi Pada Perusahaan Yang Terdaftar di BEI). PEKBIS (Jurnal Pendidikan Ekonomi Dan Bisnis), 2(03).

Budiasih, I., 2009. Faktor-faktor yang mempengaruhi praktik perataan laba.jurnal ilmiah akuntansi dan bisnis, 4(1).

Cornett, M.M., McNutt, J.J. and Tehranian, H., 2009. Corporate governance and earnings management at large US bank holding companies. Journal of Corporate finance, 15(4), pp.412-430.

Djamaluddin, S. and Wijayanti, H.T., 2008. Analisis Perubahan Aktiva Pajak Tangguhan dan Kewajiban Pajak Tangguhan Untuk Mendeteksi Manajemen Laba. Jurnal Akuntansi dan Manajemen Indonesia, 19(3), pp.139-153.

Gunawan, I.K., Darmawan, N.A.S., SE, A. and Purnamawati, I.G.A., 2015. Pengaruh ukuran perusahaan, profitabilitas, dan leverage terhadap manajemen laba pada perusahaan manufaktur yang terdaftar di Bursa Efek Indonesia (BEI). JIMAT (Jurnal Ilmiah Mahasiswa Akuntansi) Undiksha, 3(1).

He, L., Wright, S., Evans, E. and Crowe, S., 2007. Earnings management in Australia under new ASX corporate governance guidelines. In Accounting Association of Australia and New Zealand Conference (2007).

Herdawati. 2015. Analisis Pengaruh Perencanaan Pajak dan Beban Pajak Tangguhan terhadap Manajemen Laba (Studi Kasus pada Perusahaan Manufaktur yang Tercatat di Bursa Efek Indonesia). Skripsi. Makassar : Program Studi Akuntansi Fakultas Ekonomi dan Bisnis Universitas Hasanuddin.

Hotimah, H., 2014. Pengaruh Perencanaan Pajak Terhadap Manajemen Laba. Esensi: Jurnal Bisnis dan Manajemen, 4(2).

Ifada, L.M. and Wulandari, N., 2015. THE EFFECT OF DEFERRED TAX AND TAX PLANNING TOWARD EARNINGS MANAGEMENT PRACTICE: AN EMPIRICAL STUDY ON NON MANUFACTURING COMPANIES LISTED IN INDONESIA STOCK EXCHANGE IN THE PERIOD OF 2008-2012. International Journal of Organizational Innovation, 8(1).

Mahariana, I.D.G.P. and Ramantha, I.W., 2014. Pengaruh Kepemilikan Manajerial dan Kepemilikan Institusional terhadap Manajemen Laba Pada Perusahaan Manufaktur di BEI. E-Jurnal Akuntansi, 7(3), pp.688-699.

Minanari, R.A.K., 2017. Effect of Deferred Charges, Leverage and Size of Management Company Earnings (Empirical Study at Companies Jakarta Islamic Indes (JII) Listed in Indonesia Stock Exchange Index Period 20122015. Research Journal of Finance and Accounting, 8(12).

Mohamad, V., Zulkifli, B. and Nilawati, Y. 2015. Pengaruh Return On Asset (ROA) dan Leverage terhadap Praktik Manajemen Laba Pada Perusahaan Manufaktur Yang Terdaftar Di Bursa Efek 
Indonesia. Jurnal Akuntansi. Universitas Negeri Gorontalo.

Ningrat, H.K., 2014. Analisis Beban Pajak Tangguhan Dalam Mendeteksi Profitabilitas Manajemen Laba. Skripsi Mahasiswa Universitas Hasanuddin.

Pindiharti, D., 2011. Pengaruh aktiva pajak tangguhan, beban pajak tangguhan akrul terhadap earning management'studi empiris pada perusahaan manufaktur di Bursa Efek Insdonesia.

Siregar, S.V. and Utama, S., 2008. Type of earnings management and the effect of ownership structure, firm size, and corporate-governance practices: Evidence from Indonesia. The international journal of accounting, 43(1), pp.1-27.

Trisnawati, R. and Nugraheni, D., 2015. The Analysis Of Information Asymmetry, Profitability, And Deferred Tax Expense On Integrated Earning Management. South East Asia Journal of Contemporary Business, Economics and Law, 7(1), pp.17-24.
Tundjung, G.M.M. and Haryanto, H., 2015. Pengaruh Beban Pajak Tangguhan Terhadap Manajemen Laba (Studi Empiris Pada Perusahaan Manufaktur Yang Terdaftar Di Bursa Efek Indonesia) (Doctoral dissertation, Fakultas Ekonomika dan Bisnis).

Wirawati, N.G.P., Dwija, I.G.A.M.A. and Wirasedana, I.W.P., 2018. Pengaruh Kebijakan Deviden, Kompensasi, dan Leverage pada Manajemen Laba di Perusahaan Manufaktur. KRISNA: Kumpulan Riset Akuntansi, 10(1), pp.3240.

Xie, B., Davidson III, W.N. and DaDalt, P.J., 2003. Earnings management and corporate governance: the role of the board and the audit committee. Journal of corporate finance, 9(3), pp.295-316.

Yatulhusna, N., 2015. Pengaruh profitabilitas, leverage, umur, dan ukuran perusahaan terhadap manajemen laba (studi empiris pada perusahaan manufaktur yang terdaftar di Bursa Efek Indonesia periode 2010-2013). 